\title{
Byssinosis: a review
}

\author{
R McL Niven, C A C Pickering
}

Over the past two decades the cotton industry in the United Kingdom has suffered from a major recession. Cheaply produced and subsidised imported cotton has decimated a major industry which was responsible for much of the industrial wealth in the north west of England. With the diminishing industry, we are also losing one of the most studied but least understood occupational diseases, byssinosis. Our own study of the working population of the remaining Lancashire textile mills is now in its seventh year, with up to 1500 workers having been seen each year (although the recession has reduced this to 1000 in the last two years). Of the original 10 mills included in the study, only two remain in production.

The early reports of the health of cotton workers describe a "work-related cough associated with a sensation of uneasiness beneath the sternum" and later the unusual periodicity of the disease "all the workers have told us that the dust bothered them much less on the last days of the week than on Monday or Tuesday". The workers attributed this to the interruption of work making them lose, in part, their habituation to the dust. ${ }^{2}$

Over a century later Sir Richard Schilling performed the first substantial epidemiological studies of cotton workers and described and classified the specific features recognised in the UK as byssinosis. ${ }^{3}$ Over recent years new terminology has been introduced, dividing byssinosis into "acute" and "chronic" forms. Acute byssinosis refers to the acute airways response which occurs in approximately a third of volunteers exposed to cotton dust for the first time. Substantial falls in $\mathrm{FEV}_{1}$ exceeding $30 \%$ have been reported in artificial cardroom exposures to cotton dust in cotton naive subjects. ${ }^{4}$ This type of response may account for the substantial labour turnover observed during the first year of employment in cotton spinning mills. A study of Finnish cotton spinning mills reported that one in 10 employees left within two weeks and one in four within three months of taking up employment. ${ }^{5}$ The pathophysiological process underlying this response is unknown, but probably represents a mixture of acute irritant or toxic reactions following exposure to cotton dust. Chronic byssinosis is applied to the symptoms and disability described in the early epidemiological studies which may develop after 20-25 years exposure to cotton dust. The term byssinosis in this article will relate to the disease as described in these early epidemiological studies.

\section{Symptoms}

The classical form of byssinosis is characterised by a feeling of chest tightness and difficulty in breathing which the worker experiences as being most severe on the first day of the working week after a period of absence from work. The symptoms continue after the individual has finished work and may even progress during the evening. However, they are perceived as being less troublesome on subsequent days. The reason for this lessening of symptoms remains unknown.

The affected worker will not experience the symptoms until he or she has worked for many years in the industry; indeed, it may be seen for the first time 25 years after starting to work in the industry and is rare in individuals continuously exposed for less than 10 years. This clearly distinguishes it from occupational asthma, and makes specific sensitisation an unlikely cause.

The duration and frequency of the symptoms are used as the basis for the original classification of the disease, which was later updated to include impairment of lung function. ${ }^{67}$ The classification included clinical grades $\mathrm{C} 1 / 2$ to $\mathrm{C} 3$ and functional grades $\mathrm{F} 0$ to $\mathrm{F} 3$, based on symptoms and ventilatory impairment, but this grading system had important limitations. The clinical grades did not take into account the acute irritant effects of exposure to cotton dust or the changes in lung function which may occur in the absence of symptoms.

It was traditionally accepted that the disease progressed from one grade to another, presumably as a result of continuing exposure. However, two longitudinal studies have shown that this is unlikely to be the case ${ }^{89}$ as, in both studies, individuals were seen to commence at grade 2 or 3 byssinosis without passing through the preceding grades. Individuals have also been seen whose symptoms have remitted and who have therefore gone down grades despite continuing exposure to cotton dust.

Symptoms other than those described by Schilling are seen in workers with byssinosis. In our own study workers with byssinosis have reported other symptoms, including cough and wheeze. Other workers describe cough and wheeze to be most severe on the first day of the working week but in the absence of chest 
WHO grading system for byssinosis

\begin{tabular}{|c|c|}
\hline Classification & Symptons \\
\hline Grade 0 & No symptoms \\
\hline \multicolumn{2}{|r|}{ Chest rightness and/or shortness of breath on most of first } \\
\hline Grade B1 & $\begin{array}{l}\text { Chest tightness and/or shortness of breath on most of first } \\
\text { days back at work }\end{array}$ \\
\hline Grade B2 & $\begin{array}{l}\text { Chest tightness and/or shortness of breath on the first and } \\
\text { other days of the working week }\end{array}$ \\
\hline \multicolumn{2}{|l|}{ Respiratory tract irritation: } \\
\hline Grade RTI 2 & $\begin{array}{l}\text { Persistent phlegm (i.e. on most days during } 3 \text { months of the } \\
\text { year) initiated or exacerbated by dust exposure }\end{array}$ \\
\hline Grade RTI 3 & $\begin{array}{l}\text { Persistent phlegm initiated or made worse by dust exposure } \\
\text { either with exacerbations of chest illness or persisting for } 2 \\
\text { years or more }\end{array}$ \\
\hline \multicolumn{2}{|l|}{$\begin{array}{l}\text { Lung function: } \\
\text { Acute changes }\end{array}$} \\
\hline No effect & $\begin{array}{l}\text { A consistent decline in } \mathrm{FEV}_{1} \text { of less than } 5 \% \text { or an increase } \\
\text { in } \mathrm{FEV}_{1} \text { during the work shift }\end{array}$ \\
\hline Mild effect & A consistent $t^{3}$ decline of $5-10 \%$ in $\mathrm{FEV}_{1}$ during the work shift \\
\hline Moderate effect & $\begin{array}{l}\text { A consistent }{ }^{2} \text { decline of } 10-20 \% \text { in } \mathrm{FEV}_{1} \text { during the work } \\
\text { shift }\end{array}$ \\
\hline $\begin{array}{l}\text { Severe effect } \\
\text { Chronic changes }\end{array}$ & A decline of $20 \%$ or more in $\mathrm{FEV}_{1}$ during the work shift \\
\hline No effect & $\mathrm{FEV}_{\mathrm{l}}^{\mathrm{b}} 80 \%$ of predicted value ${ }^{\mathrm{c}}$ \\
\hline $\begin{array}{l}\text { Mild to moderate effect } \\
\text { Severe effect }\end{array}$ & FEV ${ }^{b} 60-79 \%$ of predicted value ${ }^{c}$ \\
\hline Severe effect & $\mathrm{FEV}_{1}^{\mathrm{b}}$ less than $60 \%$ of predicted value ${ }^{\mathrm{c}}$ \\
\hline
\end{tabular}

${ }^{a}$ A decline occurring in at least three consecutive tests made after an absence from dust exposure of two days or more.

${ }^{b}$ Predicted values should be based on data obtained from local populations or similar ethnic and social class groups.

' By a preshift test after an absence from dust exposure of two days or more.

tightness, and therefore do not fulfil the criteria for byssinosis. This group of workers is very similar to those with byssinosis in terms of their demographic features and exposure histories, and it seems likely that these individuals are suffering from the same disease process which is being expressed in a different way.

Respiratory disease and symptoms not temporally related to the working environment are also more common in the cotton textile environment. Berry described chronic bronchitis as being more common among cotton workers, ${ }^{8}$ and a recent review of our own data on nearly 3000 textile workers has confirmed these findings. The size of the cohort allowed sufficient numbers of never smoking cotton workers to be examined. The effect of current exposure to cotton compared with the control group was found to be at least as important as smoking, once other confounders had been accounted for.

In view of the varying clinical and functional respiratory features described in cotton workers, a second grading system for "byssinosis" has been proposed by the World Health Organisation which includes the classical symptoms of byssinosis, symptoms in keeping with chronic bronchitis, and both measures of across shift and permanent reductions in lung function (table). ${ }^{10}$

It has been postulated that acute byssinotic responses are related to an individual's airways reactivity. A study of healthy, cotton naive, subjects exposed to cotton dust showed that the cotton responders had significantly more reactive airways than non-responders, using a methacholine challenge system. ${ }^{11}$ In view of the known association between atopy and airways reactivity, it may be anticipated that atopic individuals would not tolerate exposure to cotton dust in the workplace. This is supported both by work of Honeybourne et al, who found a lower prevalence of atopy in a group of byssinotic workers than in a control group, ${ }^{12}$ and by our own field experience of asthmatic subjects entering the industry and having to leave due to increasing asthmatic symptoms.

\section{Respiratory physiology}

Changes in lung function have frequently been demonstrated in cotton workers - both acutely, across shift, and chronically - as estimated from cross sectional and prospective longitudinal studies. Some of these studies have shown across shift falls which are larger on the first working day of the week than on later days. ${ }^{1314}$ These findings support the symptom periodicity of the disease. However, in one study of byssinotic subjects, while the across shift fall was largest on the first day of the working week, the forced expiratory volume in one second $\left(F E V_{1}\right)$ after the shift was lowest on the last day of the week and the across shift falls became progressively smaller during the study week. ${ }^{15}$ It may be that the extent of change in lung function associated with the working shift determines the severity of symptoms, perhaps combined with a degree of habituation or conditioning to a lower level of lung function.

While most studies have concentrated on forced expiratory volumes, some studies have shown larger changes in the calibre of the small airways $^{16-18}$ which have led to the suggestion that the disease process starts in the smaller peripheral airways. ${ }^{19}$ Changes are greater for workers diagnosed as having byssinosis or chronic bronchitis than in asymptomatic workers and this is not affected by the smoking status of the individual. ${ }^{1520}$

No changes in gas transfer have been demonstrated in workers exposed to hemp, flax, or cotton, ${ }^{17}$ but in a challenge study of previous mill workers changes in arterial gas tensions were found and correlated to falls in $\mathrm{FEV}_{1}$ after exposure to hemp dust. ${ }^{21}$

While several studies have shown that cotton workers as a cohort have lower lung function than predicted, ${ }^{223}$ few have successfully observed a decline in lung function. One recent study in the USA has demonstrated that specific groups of cotton workers experience an excess decline in lung function compared with control workers with a mean annual decline of $57.4 \mathrm{ml}$ in the smoking/high dust exposure group. ${ }^{20}$ Both this study and our own have been hampered by the realisation that the chosen control population of man-made fibre workers, while relatively asymptomatic, have also been shown to have an excess decline in lung function, particularly in terms of vital capacity.

In addition to changes in lung function, cotton workers have changes in airways reactivity. Fishwick and Pickering demonstrated that byssinosis was associated with increased bronchial reactivity in $78 \%$ of workers with byssinosis and $37 \%$ of those with non-specific work related symptoms, in comparison to a matched (age, sex, ethnic origin, smoking status, and workroom) group of asymptomatic workers in whom increased bronchial reactivity was identified in only $17 \% .^{22}$ The changes in both reactivity and small airway calibre have given rise to the 
suggestion that byssinosis is an asthma-like condition of the small airways. ${ }^{24}$

Warburton et al recently continued this work by observing the changes in bronchial reactivity across a working week. Bronchial reactivity was demonstrated as being greatest after the end of the first shift of the week in workers with byssinosis but not in those with non-work related lung disease such as chronic bronchitis. ${ }^{25}$

Modest across shift decrements in $\mathrm{FEV}_{1}$ have recently been shown to be strongly predictive of long term impairment of lung function in cotton workers. ${ }^{26}$

\section{Pathology}

The pathological features of byssinosis have not been clearly defined, partly because of the difficulty in making specific diagnoses in life and also because of the presence of confounding features such as cigarette consumption which influence pathological changes. In the studies performed, insufficient numbers of never smoking byssinotic workers have been studied to distinguish between the non-specific features of smoking related pulmonary disease and any specific pathology associated with byssinosis.

A number of contradictory findings have been reported. Firstly, in a study by Edwards et al evidence of mucous gland hyperplasia and smooth muscle hypertrophy were demonstrated. ${ }^{27}$ These features are non-specific and can be seen in patients with both chronic bronchitis and asthma. ${ }^{28} \mathrm{~A}$ later study confirmed the finding of increased mucous gland hyperplasia ${ }^{29}$ but, in addition, suggested that the changes occurred irrespective of whether the individual had ever smoked (the numbers were unfortunately small and exposure not satisfactorily documented). Both studies failed to show a relationship between byssinosis and emphysema or interstitial lung fibrosis.

These studies investigated necroscopic changes within a variable time period between cessation of exposure to cotton dust and death. No studies have yet been performed in which either bronchial biopsy or bronchial lavage specimens have been taken from individuals with a well substantiated diagnosis of chronic byssinosis.

Bronchoalveolar lavage studies have been performed after exposure of both animals and human volunteers to cotton dust or dust extracts. Unfortunately these have been done predominantly on volunteers rather than individuals with chronic byssinosis. Variable changes have been identified, but neutrophil recruitment appears to be the most consistent finding. ${ }^{30}$ Whether such neutrophil recruitment is a feature of chronic byssinosis is unknown.

There remains doubt as to whether byssinosis is associated with any excess mortality and morbidity once exposure has ceased. Early studies suggested that there was no effect on survival in cotton workers. ${ }^{31}$ Such studies have been flawed by low response rates and by a lack of comparison between workers with and without respiratory symptoms. More recently, Hodgson achieved a response rate of over $90 \%$ and, while confirming an expected "healthy worker" effect, he also identified an increased mortality in workers who were diagnosed as having byssinosis. ${ }^{32}$

\section{Epidemiology}

Epidemiological studies have shown that the prevalence of the disease in the UK has been falling continuously since the original studies of Schilling recorded a rate of around $50 \%$ in workers in the dustiest parts of the cotton spinning process. ${ }^{33}$ More recent studies have reported prevalence rates of $10 \%$ amongst these high risk workers, ${ }^{34}$ while current rates from our own prospective study suggest an overall prevalence of $3 \%$.

While the reduction in prevalence of the disease has been explained by a reduction in dust exposure, there is little evidence to confirm a continued fall in dust levels. Indeed, it appears that, as the industry has striven to survive in a period of recession, increased machine running speeds to increase productivity have been achieved at the expense of increased dust exposures. ${ }^{35}$ Whether the increased use of respiratory protection will counterbalance the recent increase in dust levels remains to be seen, but it is unlikely that the disease will disappear from the working population in the UK as it has in the USA where technological improvements have resulted in much lower exposures to dust. ${ }^{36}$

Similar prevalence rates of byssinosis as experienced in the UK in the 1950s and 1960s are now being experienced in the developing countries where cotton production is increasing. Prevalence rates of byssinosis of $30 \%$ in Indonesia, ${ }^{37} 37 \%$ in Sudan, ${ }^{38} 40 \%$ in Ethiopia, ${ }^{39}$ and up to $50 \%$ in India ${ }^{40}$ have been reported, although the same criteria for diagnosing byssinosis have not been used in all these studies. However, it appears that, while the disease is disappearing from the $\mathrm{UK}$ as a result of both lower dust exposures and because of industrial recession, it is becoming epidemic in parts of the world where cheap labour can be exploited.

Studies of workers exposed to flax and hemp have suggested that these dusts have a similar propensity to cause disease. ${ }^{4142}$ The so called hard fibres of jute and sisal, while historically having been considered as unable to produce byssinosis, ${ }^{43}$ may have a low capacity to produce the disease. ${ }^{44}$

\section{Mechanisms of disease induction}

Where the actual pathophysiology of a disease remains incompletely resolved, it is not surprising that the mechanisms of disease induction are similarly uncertain. Byssinosis is not a disease of exposure to inert dust. Studies have shown that washed cotton, while producing very similar dust exposure levels, has a reduced ability to produce physiological changes in affected individuals. ${ }^{45}$ In addition, while cotton contains a certain amount of histamine, the concentrations are too low to produce bronchoconstriction in man. ${ }^{46}$ An allergic 
IgE mediated mechanism, while plausible from the highly antigenic composition of cotton dust and its contaminants, is unlikely as there is no relationship between atopy and disease. ${ }^{47} \mathrm{~A}$ non-IgE immunological mechanism has certain evidence to support it and remains plausible. Precipitating IgG antibody to an antigen in cotton is present in cotton workers and exposed controls. Its titres are highest in byssinotic workers and are greater at the beginning of the working week than at the end. ${ }^{489} \mathrm{Un}$ fortunately, challenge with the identified compound failed to produce any pulmonary change to support the theory.

Complement activation has been reported from both arms of the cascade. ${ }^{5051}$ Polymorphonuclear recruitment and activation has also been demonstrated in challenges with cotton dust extract on experimental animals ${ }^{5253}$ and in the nasal passages of current workers. ${ }^{16}$ Activation of the arachidonic cascade has also been described ${ }^{54}$ and, while these mechanisms are plausible, no single explanation is satisfactory.

\section{Aetiological agents}

The airborne environment of the cotton mill is a milieu of different biochemical and microbiological agents capable of producing pulmonary reactions. It is certain that byssinosis is not a simple reaction to inert dust but is a response to one or a combination of these compounds.

Bract is the part of the cotton harvest which is not cotton fibre itself. It is predominantly dried leaf or plant debris collected during harvesting, but may also contain some soil. It contains a mixture of polyphenolic compounds with immunological activity and microbiological flora. Exposure of cotton workers to bract extracts causes bronchoconstriction. ${ }^{11}$ However, no good epidemiological data have been gathered to demonstrate a relationship between bract extract and disease. Such data are vital to identify a causal link with a disease of such prolonged development.

Tannins are present in cotton dust and have been shown to occur at levels capable of producing airway smooth muscle and epithelial changes in experimental animals. ${ }^{55}$ Tannins are also considered to be the cause of a byssinosislike disease of herbal tea workers who experience symptoms on the first working day similar to those of cotton workers. ${ }^{56}$ There is, as yet, no clear mechanistic role for tannins, however, and no epidemiological studies have included measurement of tannins.

Much of our own work has focused on the microbiological contaminants of cotton dust. Fungi, with antigenic properties and thermophilic actinomycetes capable of producing alveolitides, have been reported in significant concentrations. ${ }^{57}$ No relationship was identified between fungal exposure and disease in a study by Cinkotai and Whittaker, ${ }^{58}$ but a strong relationship was found between bacteria (both Gram positive and Gram negative) and byssinosis. These findings have been confirmed by our own study where strong relationships were found between measures of all Gram positive and Gram negative bacteria and fungal exposures and chronic byssinosis. ${ }^{59}$ Unfortunately, it is apparent that, where the conditions favour the high exposure to one microbiological agent, then all are prevalent. The relationships are strongest for Gram negative bacteria but it was statistically impossible to confirm whether this was causal or related to co-association.

Endotoxin is a name given to a heterogeneous group of lipopolysaccharides which have been shown to be the cause of toxic reactions in Gram negative septicaemia. ${ }^{60}$ Inhalation of endotoxin causes both bronchoconstriction ${ }^{61}$ and, in animal models, an inflammatory response including polymorphonuclear recruitment. ${ }^{62}$ After chronic exposure, changes compatible with chronic bronchitis have been demonstrated histologically. ${ }^{63}$ In acute exposure studies in humans challenged with cotton dust, endotoxin levels were measured and correlated most closely with bronchoconstriction compared with the other hygiene exposure parameters. ${ }^{4}$ In our own epidemiological study there is a very close correlation between current levels of endotoxin exposure and the prevalence of byssinosis. ${ }^{64}$ However, exposure to endotoxin is known to occur in a number of other industries where organic dust is present - for example, swine confinement buildings, ${ }^{65}$ poultry farms, ${ }^{66}$ and hay handling, ${ }^{67}$ - but workers in these industries, while potentially at greater risk of respiratory disease, do not suffer a byssinosislike syndrome. A dose effect has been suggested as a possible explanation for this as existing studies have failed to compare exposure levels in different industries. Recent work in our centre has shown that, in some of these industries, exposure to endotoxin is much greater than in the cotton industry. ${ }^{68}$ If endotoxin were to explain all the features of byssinosis, it would have to relate to the chronicity of exposure or to an effect of mixed exposures.

\section{Treatment and prevention}

The treatment for affected individuals is similar to that for patients with occupational asthma. Prevention of further exposure, while preferred, has not been regularly achieved - partly because of the uncertainty as to the long term prognosis of the disease even if exposure continues, and partly because affected workers are unable to change to alternative employment. Cessation of exposure in an occupational disease should be recommended, particularly as recent studies have shown increased mortality in workers with byssinosis.

Both bronchodilators and anti-inflammatory agents can be used to ameliorate symptoms and inhaled steroids are probably more potent than sodium cromoglycate in the chronic form of the disease. ${ }^{69}$

The long term aim must be to prevent the disease by a reduction in dust exposure or exposure to the specific agent once this has been identified. As has been demonstrated by the cotton industry in the USA, technological 
investment can bring both improved productivity with reduced incidence of the disease. $^{36}$

\section{Conclusions}

It is clear that short term exposure to cotton dust for some workers is associated with acute respiratory symptoms and long term exposure is still associated with the classical form of byssinosis. The disease is characterised by small airway changes, both physiologically and histologically, and by increased bronchial reactivity. Exposure to cotton dust is also associated with an excessive decline in lung function, irrespective of the presence of byssinosis itself. The unusual periodicity of chronic byssinosis remains the most specific feature of the disease which otherwise might be quite indistinguishable from occupational asthma/ bronchitis. The underlying mechanisms are uncertain, but probably involve an inflammatory reaction secondary to an immunological or endotoxin induced process. While it will be a rare diagnosis for many physicians in the UK, the disease will have worldwide relevance for many years to come.

1 Kay JP. Observations and experiments concerning molecular irritation of the lungs as one source of tubercular consumption; and on spinner's phthisis. North Engl Med Surg f $1831 ; 1: 348-63$

2 Mareska J, Heyman J. Enquête sur le travail et la condition physique et morale des ouvriers employee dans les manufactures de coton, à Gand. Ann Soc Med Gand 1845; 16.11:5, 199.

3 Schilling RSF. Byssinosis in cotton and other textile workers. Lancet 1956;ii:261-5.

4 Castellan RM, Olenchock SA, Hankinson JL, Millner PD, Cocke JB, Bragg CK, et al. Acute bronchoconstriction induced by cotton dust: dose-related responses to endotoxin and other dust factors. Ann Intern Med 1984;101: 157-63.

5 Koskela R-S, Klockars M, Jarven E. Mortality and disability among cotton mill workers. Br FInd Med 1990;47:384-91.

6 Roach SA, Schilling RSF. A clinical and environmental study of byssinosis in the Lancashire cotton industry. $\mathrm{Br}$ Ind Med 1960:17:1-9.

7 Schilling RSF, Vigliani EC, Lammers B, Valic F, Gilson JC. A report on a conference on byssinosis. 14th International Conference on Occupational Health, Madrid, 1963. International Congress Series. No.62. Amsterdam: Excerpta Medica, 137-44.

8 Berry G, Molyneux MKB, Tombleson JBL. Relationship between dust level and byssinosis and bronchitis in Lancashire cotton mills. Br f Ind Med 1974;31:18-27.

9 Fletcher AM, Fishwick D, Pickering CAC, Niven RMcL. A two year study of respiratory symptoms in cotton and man-made fibre textile workers. Proceedings of the 15th man-made fibre textile workers. Proceedings of the 15th National Cotton Council, USA, 1991.

10 World Health Organisation. Recommended health-based occupational exposure limits for selected vegetable dusts. Report of a WHO study group. Technical Report Series $684,1983$.

11 Schachter EN, Zuskin E, Buck B, Witek T, Beck G, Tyler $D$. Airway reactivity and cotton bract induced bronchial obstruction. Chest 1987;1:51-5.

12 Honeybourne D, Finnegan MJ, Pickering CAC. Does atopy matter in byssinosis? New light on byssinosis. Cardiff: MRC Epidemiology Unit, 1985.

13 McKerrow CB, McDermott M, Gilson JC, Schilling RSF. Respiratory function during the day in cotton workers: a study in byssinosis. Br f Ind Med 1958;15:75-83.

14 Jones RN Carr J, Glindmeyer H, Diem J, Weill H. Respiratory health and dust levels in cottonseed mills. Thorax 1977;32:281-6.

15 Merchant JA, Halprin GM, Hudson AR, Kilburn KH, McKenzie WM, Bermanzohn P, et al. Evaluation before and after exposure - the pattern of physiological response to cotton dust. Ann NY Acad $S_{c i}$ 1974;221:38-43.

16 Merchant JA, Halprin GM, Hudson AR Kilburn $\mathrm{KH}$, McKenzie WN, Hurst DJ. Responses to cotton dust. Arch Environ Health 1975;30:222-9.

17 Zuskin E, Valic F, Butkovic D, Bouhuys S. Lung function in textile workers. Br f Ind Med 1975;32:283-8.

18 Parikh JR, Majumdar PK, Shan AR, Rao NM, Kashyap SK. Acute and chronic changes in pulmonary function among Indian textile workers. F Soc Occup Med 1990;40: $71-4$.
19 Field GB, Owen P. Respiratory function in an Australian cotton mill. Bull Eur Physiopathol Respir 1979;15:455-68.

20 Glindmeyer HW, Lefante JJ, Jones RN, Rando RJ, Abdel Kader HM, Weill $\mathrm{H}$. Exposure-related declines in the lung function of cotton textile workers. Am Rev Respir Dis 1991; 144:675-83.

21 Merino VL, Lombart RL, Marco RF, Carnicero AB, Guillen FG, Bouhuys A. Arterial blood gas tensions and lung function during acute response to hemp dust. Am Rev Respir Dis 1973;107:809-15.

22 Fishwick D, Fletcher AM, Pickering CAC, Niven RMcL Faragher EB. Lung function, bronchial reactivity, atopic status and dust exposure in Lancashire mill operatives. Am Rev Respir Dis 1992;145:1103-8.

23 Beck GJ, Schachter EN, Maunder LR, Bouhuys A. The relation of lung function to subsequent employment status and mortality in cotton textile workers. Chest 1979;4 $11-15 \mathrm{~s}$

24 Fishwick D, Pickering CAC. Byssinosis - a form of occupational asthma. Thorax 1992;47:401-3.

25 Warburton CJ, Fletcher AM, Pickering CAC, Niven RMcL Francis $\mathrm{H}$. Changes in lung function and bronchial reactivity across shifts and working week in cotton spinners. Proceedings of the Sixteenth Cotton Dust Research Conference Memphis, Tennessee, USA. National Cotton Council USA 1992.

26 Christiani DC, Ye T-T, Wegman DH, Eisen EA, Dai H-E, Lu P-L. Cotton dust exposure, across-shift drop in FEV and five-year change in lung function. Am $¥$ Respir Crit Care Med 1994;150:1250-5.

27 Edwards C, McCartney J, Rooke G, Ward F. The pathology of the lung in byssinotics. Thorax 1975;30:612-23

28 Dunhill MS, Massarella GR, Anderson JA. A comparison of the qualitative anatomy of the bronchi in normal subjects, status asthmaticus, in chronic bronchitis and in emphysema. Thorax 1969;24:176

29 Pratt PC, Vollmer RT, Miller JA. Epidemiology of pulmonary lesions in non-textile and cotton textile workers: a retrospective autopsy analysis. Arch Environ Med 1980; 35:133-7

30 Rylander R, Beijer L, Lantz R, Burrell R, Sedivy S. Modulation of pulmonary inflammation after endotoxin inhalation with a platelet activating factor antagonist (48740 RP) Int Arch Allergy Appl Immunol 1988;86:303-7.

31 Berry G, Molyneux MKB. A mortality study of workers in Lancashire cotton mills. Chest $1981 ; 79 \mathrm{~S}: 11-5$.

32 Hodgson JT, Jones RD. Mortality of workers in the British cotton industry in 1968-84. Scand $\mathcal{F}$ Environ Health 1990 16:113-20

33 Schilling RSF, Hughes JPW, Dingwall-Fordyce I, Gilson JC. An epidemiological survey of byssinosis amongst cotton workers. Br f Ind Med 1955;12:217-27.

34 Cinkotai FF, Rigby A, Pickering CAC, Seaborn D, Faragher E. Recent trends in the prevalence of byssinotic symptoms in the Lancashire textile industry. $\mathrm{Br}$ F Ind Med 1988;45: $782-9$.

35 Niven RMcL, Fishwick D, Pickering CAC, Fletcher AM, Warburton CJ, Crank P. A study of the performance and comparability of the sampling response to cotton dust of work area and personal sampling techniques. Ann Occup Hyg 1992;36:349-62.

36 Pinkham J. Cotton dust standard endures 10 years. Occup Health and Safety 1988:24-29.

37 Baratawidjaja $\mathrm{K}$. Byssinosis among 250 textile workers in Jakarta. Am $\mathcal{F}$ Ind Med 1990;45:782-9.

38 El Karim MAA, Ona SH. Prevalence of byssinosis and respiratory symptoms among spinners in Sudanese cotton mills. Am F Ind Med 1987;12:281-9.

39 Woldeyohannes M, Bergevin Y, Mgeni AY, Theriault G. Respiratory problems among cotton textile mill workers in Ethiopa. Br F Ind Med 1991;48:110-15.

40 Parikh JR, Bhagia LJ, Majumdar PK, Shah AR, Kashyap SK. Prevalence of byssinosis in textile mills at Ahmedabad, India. Br F Ind Med 1989;46:787-90.

41 Elwood PC, Pemberton J, Merrett JD, Carey GCR, McAulay IJ. Byssinosis and other respiratory symptoms in flax workers in Northern Ireland. Brf Ind Med 1965;22:27-37.

42 Zuskin E, Kanceljak B, Pokrajac D, Schacter EN, Wite TJ. Respiratory symptoms and lung function in hemp workers $\mathrm{Br} \mathcal{F}$ Ind Med 1990;47:627-32.

43 McKerrow CB, Gilson JC, Schilling RSR, Skidmore JW Respiratory function and symptoms in rope-makers. $\mathrm{Br}$ Ind Med 1965;22:204-9.

44 Thomas HF, Elwood JH, Elwood PC. Byssinosis in Belfast ropeworkers: an historical note. Ann Occup Hyg 1988.32: 249-51.

45 Petsonk EL, Olenchok SA, Castellan RM, Banks DE, Mull $\mathrm{J}$, Hankinson JL, et al. Human ventilatory responses to washed and unwashed cottons from different growing areas. $B r ₹$ Ind Med 1986;43:182-7.

46 Edwards JH, Al Zubaidy TS, Altikriti R, Bunni H. Byssinosis. Inhalation challenge with polyphenol. Chest 1985 2:215-7.

47 O'Neill CE, Reed MA, Aukrust L, Butcher BT. Studies on the antigenic composition of aqueous cotton dust extracts. Int Arch Allergy Appl Immunol 1983;72:294-8.

48 Massoud A, Taylor G. Byssinosis antibody to cotton antigen in normal subjects and in cotton card-room workers. Lancet 1964;ii:607-10.

49 Taylor G, Massoud AAE, Lucas F. Studies in the aetiology of byssinosis. Br f Ind Med 1971;28:141-51.

50 Mundie TG, Boackle RJ, Ainsworth SK. In vitro alternativ and classical activation of complement by extracts of cotton mill dust: a possible mechanism in the pathogenesis of byssinosis. Environ Res 1983;32:47-56. 
51 Kutz SA, Olenchok SA, Elliot JA, Pearson DJ, Major PC. Antibody independent complement activation by cardroom cotton dust. Environ Res 1979;19:405-14.

52 Rylander R, Norstrand A. Pulmonary cell reactions after exposure to cotton dust extract. $\mathrm{Br}$ F Ind $\mathrm{Med} 1974 ; 31$ : 220-3.

53 Schacter EN, Buck MG, Merrill WW, Askenase P, Witek TJ. Skin testing with aqueous extract of cotton bract. $\mathcal{F}$ Allergy Clin Immunol 1985;76:481-7.

54 Fowler SR, Ziprin RL, Elissalde MH, Greenblatt GA. The aetiology of byssinosis - possible role of prostaglandin F2alpha synthesis by alveolar macrophages. Am Ind Hyg Assoc 7 1981;42:445-8.

55 Cloutier MM, Rohrbach MS. Effects of endotoxin and tannin isolated from cotton bracts on airway epithelium. Am Rev Respir Dis 1986;134:1158-62.

56 Castellan RM, Boehlecke BA, Peterson Y, Theddell TD, Merchant JA. Pulmonary function and symptoms in herbal Merchant JA. Pulmonary function

57 Lacey J, Lacey ME. Micro-organisms in the air of cotton mills. Ann Occup Hyg 1987;31:1-19.

58 Cinkotai FF, Whittaker CJ. Airborne bacteria and the prevalence of byssinotic symptoms in 21 cotton spinning mills in Lancashire. Ann Occup Hyg 1978;21:239-50.

59 Niven RMcL, Fletcher AM, Pickering CAC, Fishwick D, Crank P. Airborne micro-organisms and their role in respiratory symptoms in Lancashire cotton spinning mills. Proceedings of the 15th Cotton Dust Research Conference Memphis, Tennessee, USA. National Cotton Council USA, 1991:202-4.

60 Levin J, Poore TE, Zauber NP, Oser RS. Detection of endotoxin in the blood of patients with sepsis due to gramnegative bacteria. $N$ Engl $\mathcal{F}$ Med 1970;283:1313-6.
61 Michel O, Duchateau J, Sergysels R. Effect of inhaled endotoxin on bronchial reactivity in asthmatic and normal subjects. F Appl Physiol 1989;66:1059-64.

62 Hudson RH, Kilburn KH, Halprin GM, McKenzie W. Granulocyte recruitment to airways exposed to endotoxin aerosols. Am Rev Respir Dis 1977;115:89-95.

63 Cavagna G, Foa V, Vigliani EC. Effects in man and rabbits of inhalation of cotton dust or extracts and purified endotoxins. Br F Ind Med 1969;26:314-21.

64 Niven RMcL, Fletcher AM, Pickering CAC, Fishwick D, Warburton CJ Crank P. Endotoxin exposure and respiratory symptoms in Lancashire cotton spinning mills. Proceedings of the 16th Cotton Dust Research Conference Memphis, Tennessee, USA. National Cotton Council USA, 1992:222-4.

65 Donham KJ, Haglind P, Peterson Y, Rylander R. Environmental and health studies in swine confinement vironmental and health studies in swin

66 Thelin A, Tegler O, Rylander R. Lung reactions during poultry handling related to dust and bacterial endotoxin levels. Eur f Respir Dis 1984;65:266-71.

67 Rask-Anderson A. Organic dust toxic syndrome among farmers. Br F Ind Med 1989;46:233-38.

68 Simpson JCG, Niven RMcL, Pickering CAC, Oldham LA, Fletcher AM, Francis HC. Animal workers respiratory symptoms, dust and endotoxin exposures. Proceedings of the 19th Cotton and Other Organic Dusts Research Conference, Memphis, Tennessee, USA. National Cotton Council USA, 1995:331-3.

69 Fawcett IW, Merchant JA, Simmonds SP, Pepys J. The effect of sodium cromoglycate, beclomethasone dipropionate and salbutamol on the ventilatory response to cotton dust in mill workers. Br f Dis Chest 1978;72:29-38. 